\title{
Charcoal remains from a tonstein layer in the Faxinal Coalfield, Lower Permian, southern Paraná Basin, Brazil
}

\author{
ANDRÉ JASPER ${ }^{1}$, DIETER UHL ${ }^{2,3}$, MARGOT GUERRA-SOMMER ${ }^{4}$, \\ ABDALLA M.B. ABU HAMAD ${ }^{5}$ and NELI T.G. MACHADO ${ }^{1}$ \\ ${ }^{1}$ Programa de Pós-Graduação em Ambiente e Desenvolvimento do Centro Universitário UNIVATES (PPGAD/UNIVATES), \\ Avenida Avelino Tallini, 171, Bairro Universitário, 95900-000 Lajeado, RS, Brasil \\ ${ }^{2}$ Senckenberg Forschungsinstitut und Naturmuseum, Senckenberganlage 25, 60325 Frankfurt am Main, Germany \\ ${ }^{3}$ Eberhard Karls Universität Tübingen, Institut für Geowissenschaften, Sigwartstraße 10, 72076 Tübingen, Germany \\ ${ }^{4}$ Instituto de Geociências, Universidade Federal do Rio Grande do Sul, \\ Avenida Bento Gonçalves, 9500, 91501-970 Porto Alegre, RS, Brasil \\ ${ }^{5}$ Department of Environmental and Applied Geology, The University of Jordan, Amman 11942, Jordan
}

Manuscript received on November 20, 2009; accepted for publication on December 1, 2010

\begin{abstract}
Fossil charcoal has been discovered in the Faxinal Coalfield, Early Permian, Rio Bonito Formation, in the southernmost portion of the Paraná Basin, Brazil. Three types of pycnoxylic gymnosperm woods recovered from a single tonstein layer are described and confirm the occurrence of paleowildfire in this area. A decrease of the charcoal concentration from the base to the top within the tonstein layer indicates that the amount of fuel declined during the deposition probably due to the consumption of vegetation by the fire. The presence of inertinite in coals overlying and underlying the tonstein layer indicates that fire-events were not restricted to the ash fall interval. The integration of the new data presented in the current study with previously published data for the Faxinal Coalfield demonstrates that volcanic events that occurred in the surrounding areas can be identified as one potential source of ignition for the wildfires. The presence of charcoal in Permian sediments associated with coal levels at different localities demonstrates that wildfires have been relatively common events in the peat-forming environments in which the coal formation took place in the Paraná Basin.
\end{abstract}

Key words: charcoal, gymnosperms, volcanic ashes, coal deposits, Gondwana, Late Palaeozoic.

\section{INTRODUCTION}

Fire plays an important role as a major source of disturbance in many modern ecosystems (Bowman et al. 2009, Flannigan et al. 2009), and it is expected that fire occurrences in many areas worldwide may change/increase drastically with changing atmosphere and climate (Flannigan et al. 2009).

Thus, it is of great interest for our understanding on the interactions among climate, fire-ecology and vegetation to study such interactions under past climate change scenarios, as these can act as long-term experiments on time-scales that are not available to neo-ecologists.

Correspondence to: André Jasper

E-mail: ajasper@univates.br
A period that is of special interest for our understanding on these interactions is the Late Paleozoic/Early Mesozoic interval, as this is the only period during the history of the Earth when the global climate changed from an icehouse into a greenhouse climate after the colonization of the continents by plants (Gastaldo et al. 1996).

About a decade ago there were only a few substantiated records of Permian charcoal (Scott 2000). However, partly sparked by this review, a number of studies has subsequently demonstrated the presence of charcoal in many Permian deposits from the Northern hemisphere; i.e., North America (DiMichele et al. 2004), Europe (Rößler 2001, Uhl and Kerp 2003, Noll et al. 2003, Uhl et al. 2004, 2008, Šimùnek and Martínek 
2009) and China (Wang and Chen 2001). In contrast, for large parts of Gondwana, the record of Permian charcoal [despite inertinites in coals (Scott 2000)] is still scarce.

Despite numerous studies on Gondwana inertinites have assumed a problematic origin (cf. Scott 2000), the first unequivocal record of charcoal as a direct paleobotanical evidence of paleowildfires on Gondwana was published by Glasspool (2000) based on material from the Late Permian of the Sydney Basin, Australia, and subsequent studies also confirmed the presence of charcoal in Permian sediments from South Africa (Glasspool 2003) and Jordan (Uhl et al. 2007). Today there is no doubt that most Permian inertinites within numerous Gondwana coals are of pyrogenic origin (e.g. Diessel 2010), and until recently only the mere presence of pyrogenic coal macerals was reported by Jasper et al. (2006) for the South American part of the Gondwana Realm.

A first detailed anatomical analysis of Late Paleozoic charcoal has been published by Jasper et al. (2008) based on material collected at the Quiteria Outcrop, Rio Bonito Formation, Lower Permian of the Paraná Basin, located in the central-eastern portion of the State of Rio Grande do Sul, Brazil. In this study, Jasper et al. (2008) demonstrated that the charcoalified remains from Quitéria were related to basic types of gymnosperm wood and fragments of lycopsids. They also inferred that potential sources of ignition for wildfires in the studied area could have been volcanic activities in the nearby areas.

According to Guerra-Sommer et al. (2008c), evidence of volcanic activity is widespread in different coal successions in southern Brazil. This is supported by the record of volcanic rocks represented by discrete and continuous horizons of clay beds identified as tonsteins interbedded within coal seams in the Candiota and Faxinal coalfields (Formoso et al. 1999, Guerra-Sommer et al. 2006, 2008a, b, c) (Fig. 1).

Ion microprobe (SHRIMP II) dating of zircons from different tonsteins within coal seams from the Candiota coal field and the uppermost coal seam of the Faxinal coalfield were performed by Guerra-Sommer et al. (2008c). The mean ages of $290.6 \pm 1.5$ myr lead to the conclusion that the formation of the main coal seams occurred during a time interval constrained to the Middle Sakmarian.
An abundant paleoflora, composed mainly of adpressions and compressions of well-preserved foliage of Glossopteridales, Cordaitales and Filicopsida, is preserved within the tonstein layer interbedded with the uppermost coal seam of the Faxinal (Guerra-Sommer 1992). Several authors (Guerra-Sommer et al. 1984, Dias and Guerra-Sommer 1994, Cazzulo-Klepzig et al. 2007, Guerra-Sommer et al. 2008b) performed palynological studies in the Faxinal Coalfield, which have demonstrated the dominance of gymnosperm pollen grains over pteridophytic spores, ratifying the results of macro-paleobotanical analyses.

Recent field trips have collected material identified as charcoal from the Faxinal Coalfield tonstein. Its good preservation allowed getting information about anatomical details of the source-plants and the volcanic event that contributed to the deposition of the material described here.

\section{GEOLOGICAL AND STRATIGRAPHIC SETTING}

According to Milani (2003), the Paraná Basin can be interpreted as an intracratonic sag basin with an area of approximately $1,400,000 \mathrm{~km}^{2}$ covering parts of southern Brazil, Paraguay, Uruguay and Argentina. Basin floor subsidence and Palaeozoic sea-level changes created a system of six second-order sequences deposited from the Ordovincian to the Late Cretaceous and separated by regional unconformities.

The material on which this study is based comes from the Faxinal Coalfield, which is part of the southeastern outcrop belt of the coal-bearing Rio Bonito Formation. This lithostratigraphic unit was associated to the base of the second-order Carboniferous - Early Triassic sequence identified by Milani (2003) for the Paraná Basin.

The Faxinal Coalfield is located in the municipality of Arroio do Ratos, $120 \mathrm{~km}$ west of Porto Alegre, Rio Grande do Sul, Brazil [UTM N6651.5/E432.7 (Fig. 1)]. According to Ribeiro et al. (1987), the precursor peats were deposited in a SE-NW trending, elongate structure, with $60 \mathrm{~km}$ length and $5 \mathrm{~km}$ width, incised in the basement and called Leão/Mariana Pimentel Paleovalley. The coalfield is actually located at downthrown structural blocks, mainly controlled by a $\mathrm{N} 40^{\circ} \mathrm{E}$ fault system, having its extent limited by subsequent erosion. The coalfield includes five coal seams (Fig. 2) 


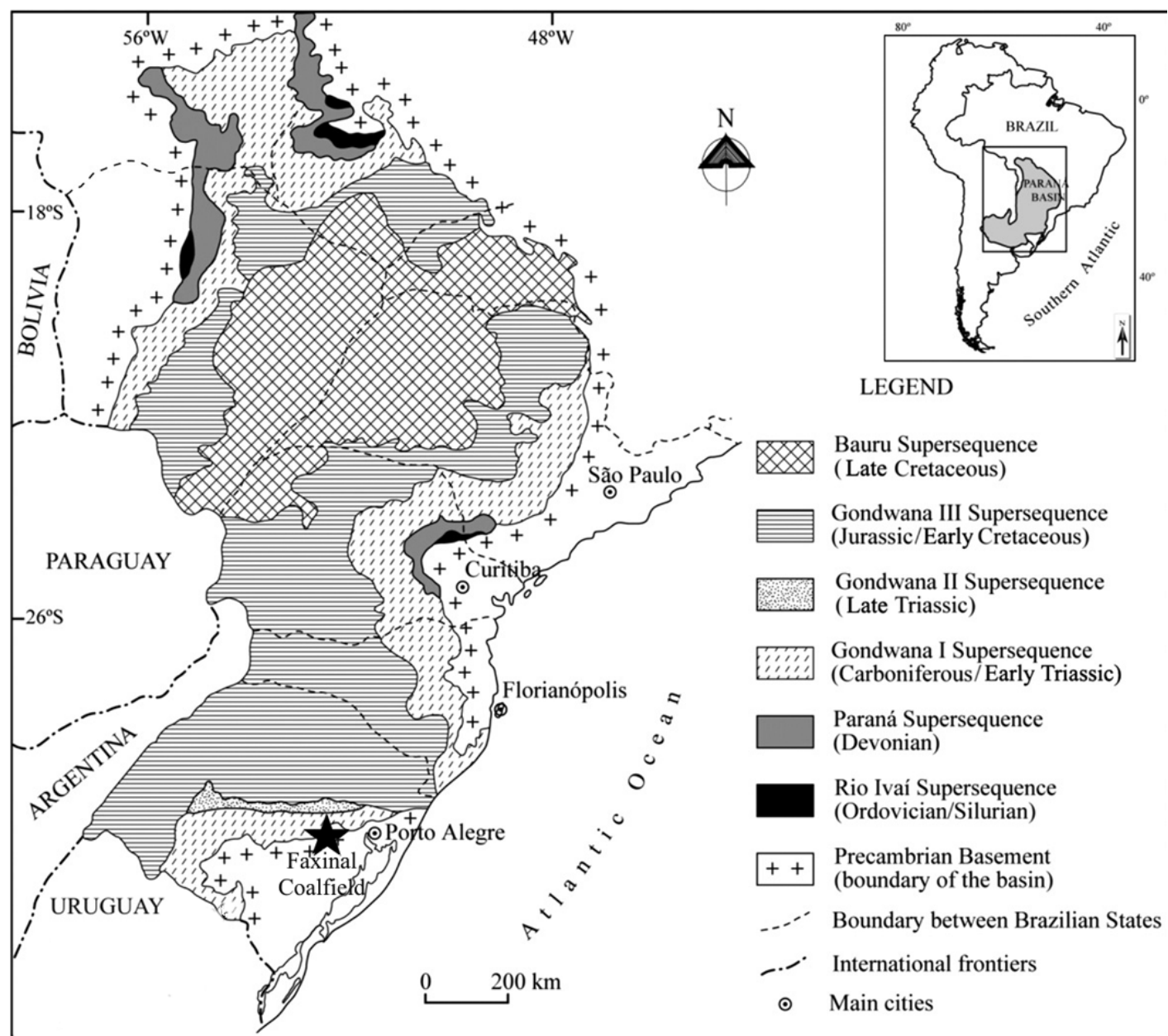

Fig. 1 - Simplified geological map of the Paraná Basin in Brazil with major tectonic elements and location of the Faxinal Coalfield.

interbedded with siltstones, mudstones, sandstones and paleosoils (Guerra-Sommer et al. 2008b). The present study is based on fossil charcoal records recovered from a light gray clay bed approximately 7 to $10 \mathrm{~cm}$ thick identified as a tonstein layer and interbedded with the uppermost coal seam.

Holz (1998) found that the Rio Bonito coal deposits occur adjacent to paralic deposits, and that coal was probably deposited in back-barrier environments. Later, Cazzulo-Klepzig et al. (2007) inferred that the particular paleoecological character of the peat-forming flora at Faxinal, which is dominated by gymnosperms, may represent local paleoenvironmental conditions, in a marine influenced lower delta plain setting. It was emphasized that these habitats were located in a more inland area in relation to other mires in the surrounding area (like the Candiota Coalfield).
Following the paleogeographic reconstructions by Scotese (2002), it can be concluded that the peat deposition occurred under a cool temperate climate, at a paleolatitude of $50^{\circ} \mathrm{S}$, in the cool temperate biome using the criteria established by Rees et al. (1999).

\section{MATERIALS AND METHODS}

During the field work, well-preserved pieces of fossil charcoal (stored in the Setor de Botânica e Paleobotânica do MCN/UNIVATES under the acronym PbU, specimens 701 to 747) have been recovered from the tonstein layer of the Faxinal Coalfield (Fig. 2).

For numeric quantitative analyses, the exposed cover area of the coalfield $\left(150 \mathrm{~m}^{2}\right)$ had been investigated with a $50 \times 50 \mathrm{~cm}$ metal-frame divided in to 9 sub-quadrants (Fig. 3). At 10 different points randomly 


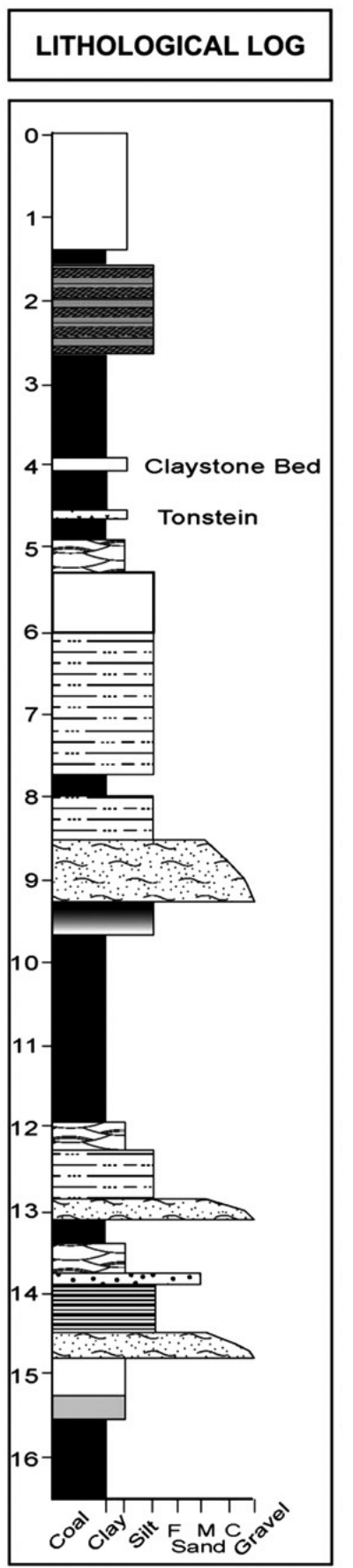

Fig. 2 - Lithological log of the Faxinal Coalfield (adapted from Guerra-Sommer et al. 2008c, fig. 8b).

selected, the frame was used to quantify the presence of charcoal in the tonstein layer in vertical intervals of $1 \mathrm{~cm}$. To quantify the abundance of charcoal, the following categories were defined: absent (no sub-quadrants with the presence of charcoal remains), rare (1 to 3 ), common (4 to 6 ) or abundant (7 to 9).
Although all charcoal fragments found at different sampling sites have been used for statistical analyses, only 75 samples have been submitted to an anatomical study.

Charcoal samples were extracted mechanically from pieces of tonstein collected at the ten analysed points with the aid of preparation needles and tweezers under a binocular microscope in the laboratory. Due to the very fragile nature of these specimens, they could not be cleaned with water or any acids to remove adhering mineral remains. The fragments were mounted on standard stubs with LeitC (Plano) and subsequently examined with the aid of a JEOL JSM 6490 LV Scanning Electron Microscope (SEM) at the Senckenberg Forschungsinstitut und Naturmuseum Frankfurt.

\section{RESULTS}

\section{ANATOMy OF THE Charcoal Remains}

The material was identified as charcoal based on the following characteristics (Jones and Chaloner 1991, Scott 1989, 2000, 2010): black color and streak, silky lustre (Fig. 4) and well-preserved anatomical details (Fig. 5A).

The charcoal fragments are relatively big (between $3.5 \times 2.2 \times 0.4$ and $1.2 \times 0.7 \times 0.2 \mathrm{~cm}$ ) with non-abraded edges. However, the woody tissues have been shattered into more or less small pieces (Fig. 5B), which were compressed during diagenesis. Due to this mechanical damage it was not possible to observe complete tissue characteristics, thus hampering a specific taxonomic/ systematic affiliation.

Three different types of wood can be distinguished, named here wood type F1 to F3 (F for Faxinal).

\section{WOOD TYPE F1}

Pycnoxylic secondary wood, in radial view tracheids are $27-42 \mu \mathrm{m}$ wide. Their radial walls exhibit uniseriate and biseriate sub-opposite to alternate bordered pits (Fig. 5C, D, E). Pits are circular to oval (4-8 $\mu \mathrm{m}$ in diameter), with circular to oval apertures and touching (Fig. 5C, E). Rays are uniseriate and 2-7 cells high, composed of parenchymatous cells with 14-19 $\mu \mathrm{m}$ wide and 18-31 $\mu \mathrm{m}$ high (Fig. 5F). Cross-field pits, leaf traces or growth rings are not visible. 


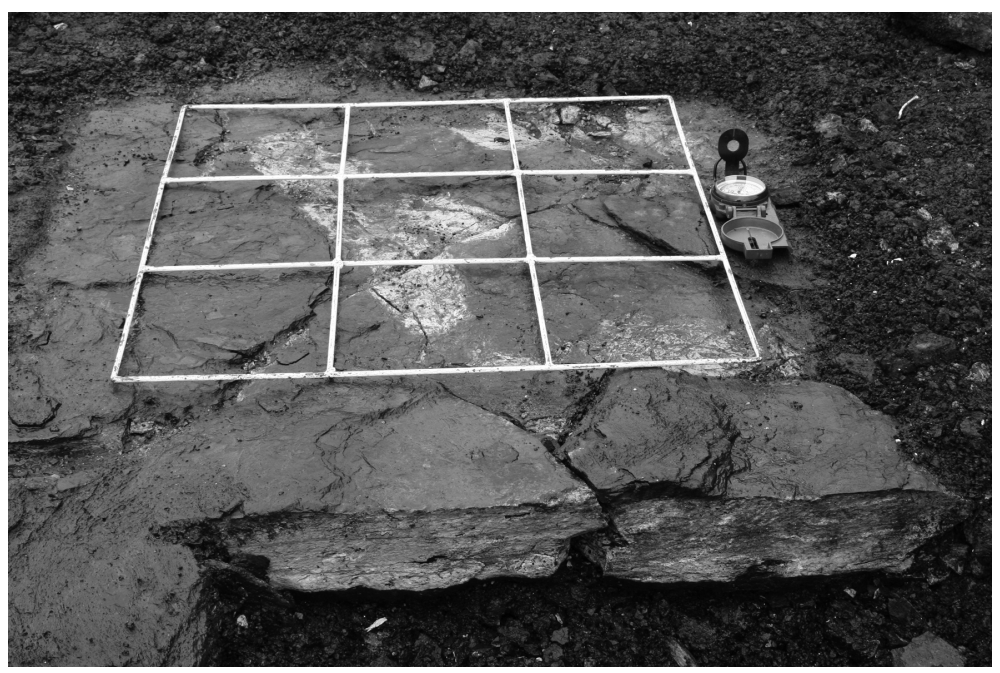

Fig. 3 - Frame $50 \times 50 \mathrm{~cm}$ (divided into 9 sub-quadrants) on the field that was used to quantify the distribution of charcoal in the tonstein layer of the Faxinal Coalfield.

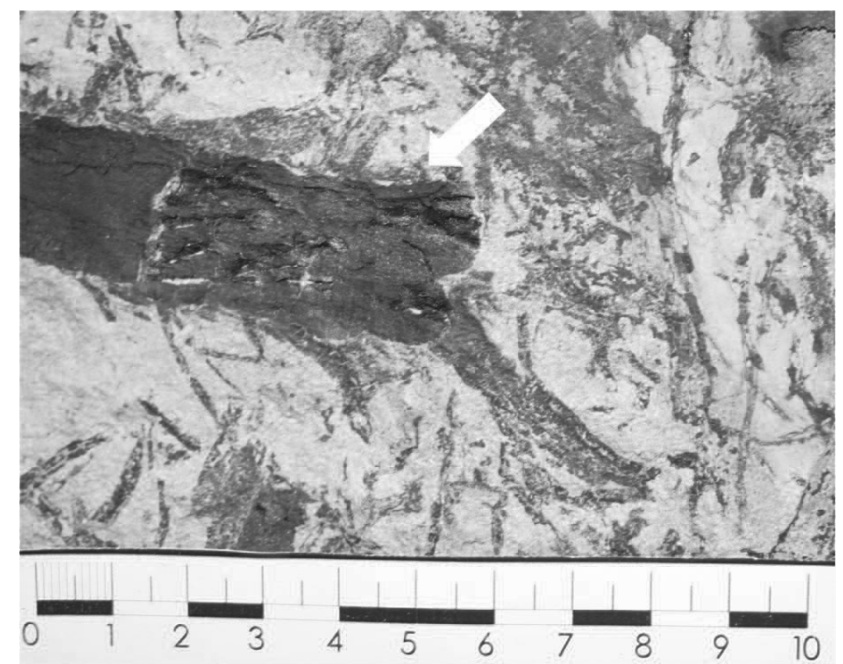

Fig. 4-Macroscopic views of tonstein sample PbU 706 highlighting a charcoal remain (arrow).

\section{WOOD TYPE F2}

Pycnoxylic secondary wood, in radial view tracheids are 23-49 $\mu \mathrm{m}$ wide. Their radial walls exhibit biseriate sub-opposite to alternate bordered pitting. Pits are circular to oval (2-5 $\mu \mathrm{m}$ in diameter) with circular to oval apertures and touching (Fig. 6A). Rays are uniseriate and 2-3 cells high (Fig. 6B), composed of parenchymatous cells with $9-13 \mu \mathrm{m}$ wide and 26-34 $\mu \mathrm{m}$ high (Fig. 5E). Cross-field pits, leaf traces or growth rings are not visible.
WoOd Type F3

Pycnoxylic secondary woods, in radial view tracheids are $20-40 \mu \mathrm{m}$ wide. Their radial walls exhibit triseriate bordered pitting, disposed alternately. Pits are circular to oval $(2-5 \mu \mathrm{m}$ in diameter), with circular to oval apertures and touching (Fig. 6C, D). Rays are uniseriate and 2-3 cells high (Fig. 6E, F), composed of parenchymatous cells with $18-41 \mu \mathrm{m}$ wide and $38-45 \mu \mathrm{m}$ high. Cross-field pits, leaf traces or growth rings are not visible. 

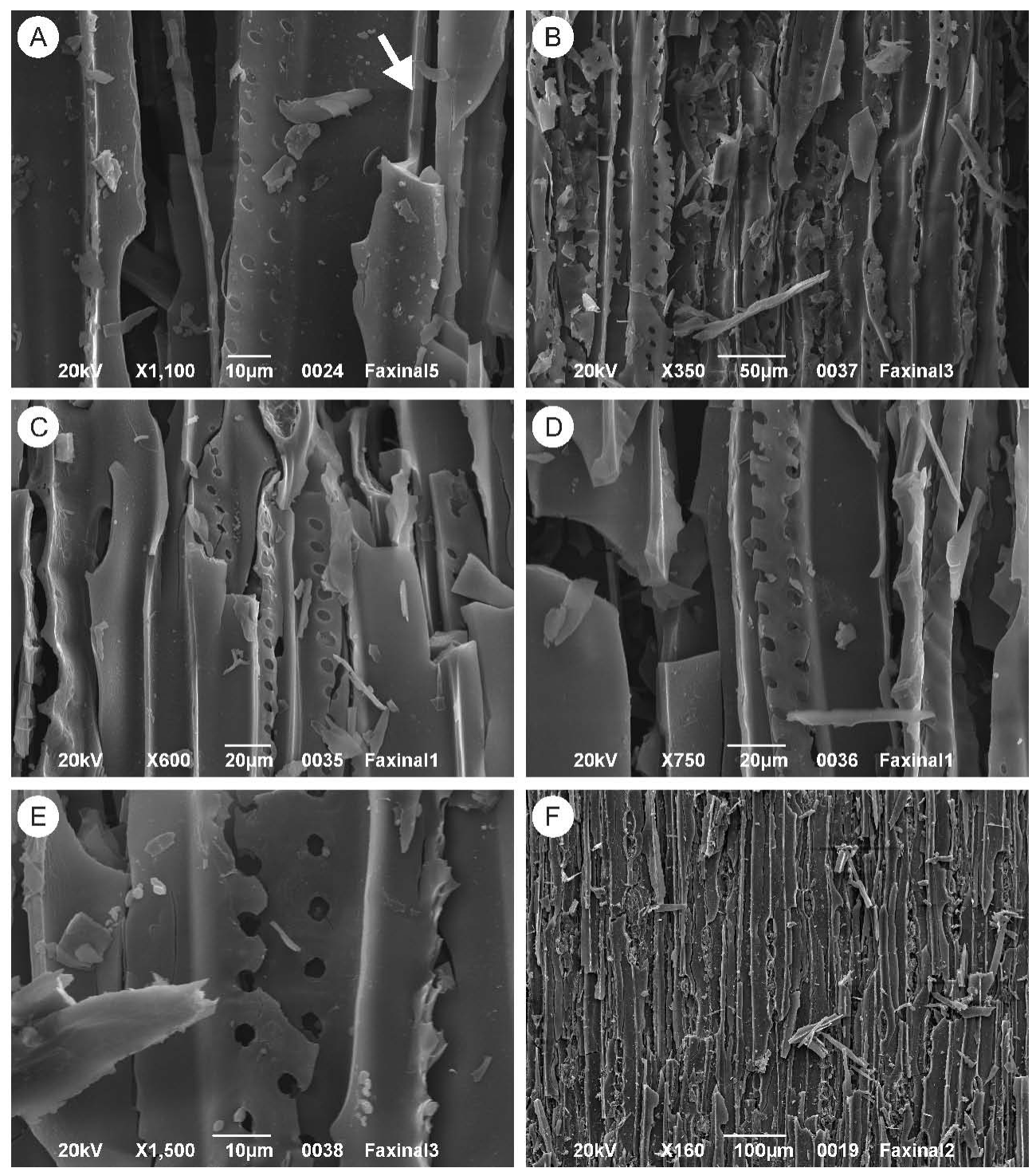

Fig. 5 - SEM images of the charcoal samples of the Faxinal Coalfield: A) tracheids with homogenized cell walls (arrow); B) tracheids shattered into more or less small pieces; C) tracheids of wood type F1 exhibiting uniseriate bordered pitting. Presence of circular to oval pits with circular to oval apertures and touching; D) tracheids of wood type F1 with biseriate bordered pitting sub-oppositely arranged; E) detail of the biseriate bordered pitting from wood type F1; F) general view of wood type F1 presenting abundant uniseriate rays.

\section{Distribution of the Charcoal REMains}

Based on a vertical analysis of the charcoal distribution within the Faxinal tonstein layer, it was observed that, in the basal levels $(1-2 \mathrm{~cm})$, the macroscopical charcoal fragments were rather abundant. Additionally, it was observed that, in most of the points, charcoals are rare in the intermediate levels $(2-5 \mathrm{~cm})$ and absent in the top levels $(6-10 \mathrm{~cm})$. The three wood types were evenly distributed through the basal and intermediate levels of the tonstein layer (Fig. 7).

\section{SIGNIFICANCE OF THE CHARCOAL REMAINS}

The first reference of inertinite fragments preserved in the coals underlying and overlying the Faxinal tonstein was made by Guerra-Sommer et al. (1984). However, these authors did not establish any relationship between 

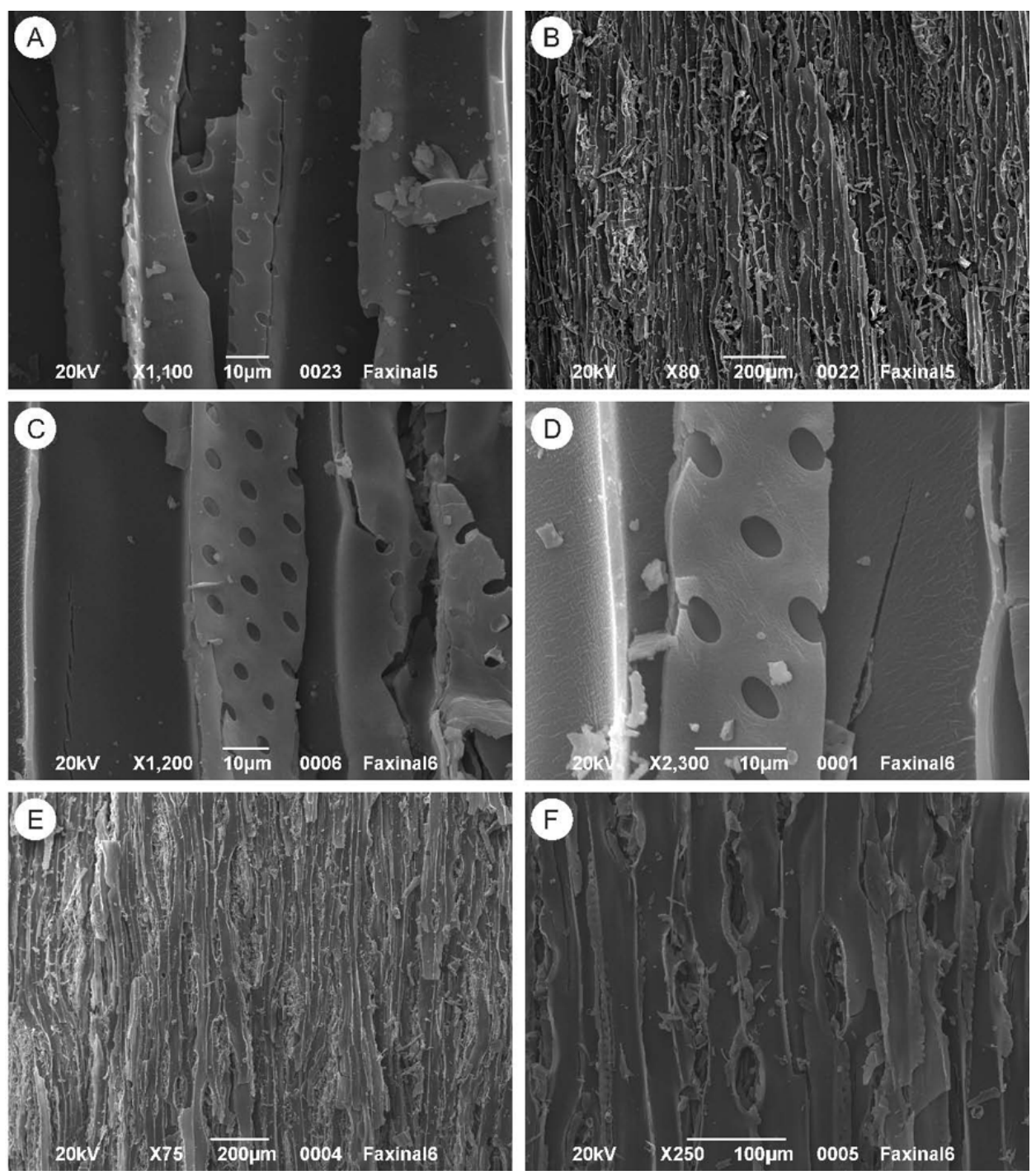

Fig. 6 - SEM images of the charcoal samples of the Faxinal Coalfield: A) tracheids of wood type F2 exhibiting biseriate bordered pitting. Note circular to oval pits with circular to oval apertures and touching; B) overview of a sample of wood type F2 presenting abundant uniseriate rays; C) tracheids of wood type F3 with alternate triseriate arranged pitting; D) detail of tracheids from wood type F3 presenting circular to oval pits with circular to oval apertures and touching; E) general view of wood type F3 with abundant uniseriate rays; F) detail of wood type F3 with uniseriate rays.

inertinite and direct evidence of paleowildfires. Otherwise, the remains had no anatomical characteristics preserved and their small size and compression prevented further analysis.

So far only Jasper et al. $(2007,2008)$ described anatomical details of charcoalified wood remains from other Late Paleozoic localities of the Paraná Basin. The araucarioid woods (Types 1 and 2) described for the
Quiteria outcrop were assigned to the gymnosperms, while the Wood Type 3 was considered as representing a secondary xylem of arborescent Lycophyta. The araucarioid woods (Types 1 and 2) described from the Quitéria outcrop, with contiguous uniseriate to biseriate and triseriate alternate pits in the tracheid wall, can probably be related to the three wood types found in the Faxinal Coalfield. 

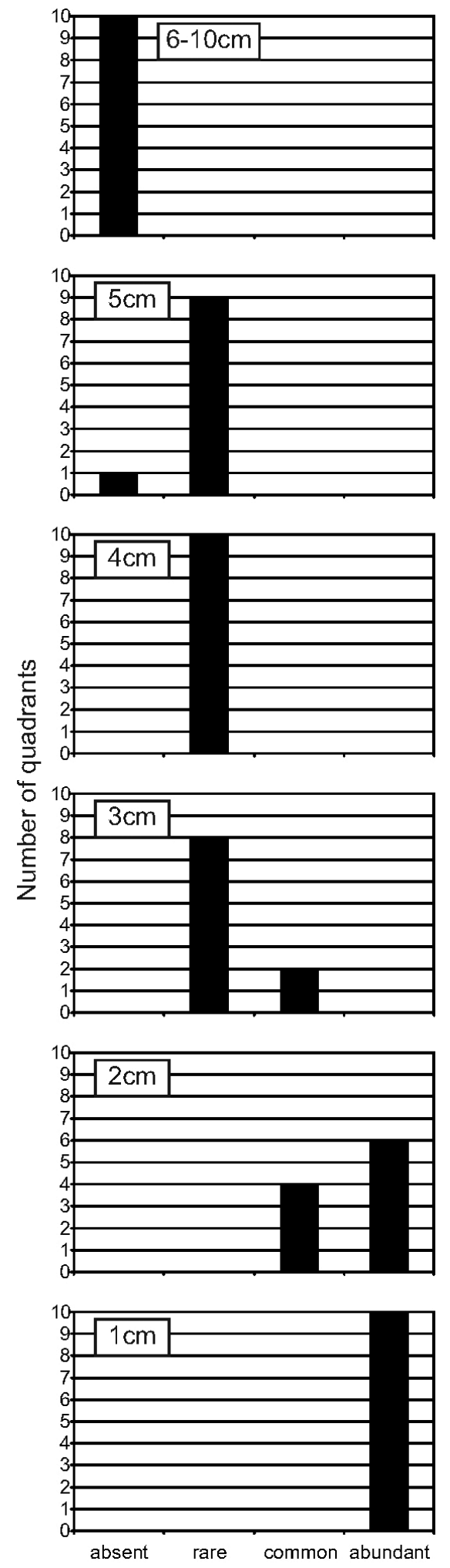

Fig. 7 - Distribution of the charcoal fragments in different levels of the tonstein from the basal (at the bottom) to upper ones showing the gradual upward disappearance of the charcoalifield plant remains.
Based on the observed anatomical characteristics, the three wood-types here described for Faxinal Coalfield can be assigned to the gymnosperms. The sub-opposite to alternate (Wood Types F1 and F2) and alternate trisseriate (Wood Type F3) disposition of bordered pits in tracheid walls correspond to features included in the morphogenus Agathoxylon Philippe and Bamford (2008). This taxon includes homoxylous gymnosperm woods with wall tracheid pitting of araucarioid type and araucarioid crossfield pitting (Bamford and Philippe 2001). This is a wood pattern very common for Late Palaeozoic gymnosperms from the northern and southern hemispheres, most of which had previously been identified as Dadoxylon Endlicher, which is not a legitimate name according to Vogellehner (1964) and Philippe (1993). According to Prevec et al. (2009), this pattern is associated with several gymnosperm groups of unknown phylogenetic affinity (Philippe and Bamford 2008) and that are assigned to taxa that historically have been attributed to differing age ranges, including the Glossopteridales. Nevertheless, the small size of the woody pieces impedes the observation of crossfield pits and, as a consequence, reliable taxonomic correlations.

Otherwise, both the big size and the absence of abraded edges in the original charcoal fragments are taphonomic parameters that indicate that they were probably not transported over a wide distance, pointing to an autochthonous/parautochthonous deposition.

According to the palaeoecological framework proposed by Cazzulo-Klepzig et al. (2007) for the Faxinal Coalfield, the precursor peats were deposited in wet forest swamp environments. Palynological analyses indicated that monosaccate pollen grains, like Cannanoropollis diffusus, Plicatipollenites malabarensis, P. gondwanensis, Limitisporites rectus, L. delasauccei, Scheuringipollenites medius and Vesicaspora wilsonii are common in both the coal seam and the tonstein, while lycopsid and fern spores are absent. Abundant well-preserved cuticle fragments showing affinity with Glossopteridophyta and Cordaitophyta were also identified.

Guerra-Sommer et al. (2008c) demonstrated that the mire was covered by ash fall coming from surrounding volcanic activities. The rich taphoflora preserved in the tonstein is predominantly represented by 
leaves of Glossopteris brasiliensis, G. papillosa, G. similis-intermittens and also reproductive organs attributed to glossopterids as Plumsteadia sennes and Platycardia sp. Leaves from Rufloria gondwanensis (cordaites) and Sphenopteris cf. ischanovensis (filicoid) are also present, but not abundant in the association (Guerra-Sommer et al. (2008b).

Taking into account these previous data and the dominance of autochthonous/parautochthonous gymnosperm charcoal remains (probably related to Agathoxylon), it is likely that the charcoal remains were formed from the burning of Glossopteris spp. woods. It can be assumed that volcanic activities in the surrounding areas were among the ignition sources for these wildfires.

The additional presence of inertinite within the coal seams (Kalkreuth et al. 2006) indicates that fires occurred more or less regularly within the mires, although so far nothing is known about the micro-stratigraphic distribution of these inertinites within the Faxinal coal seams. However, after Scott and Glasspool (2007) and Scott (2010), the frequency of this kind of maceral in the coal seams demonstrates that fire was a common event in the environment and the charcoal remains with preserved anatomical features (not inertinite) could only be preserved in the tonstein layer.

The numerical analyses of the charcoal remains along the tonstein's vertical gradient, which shows a reduction of charcoal, indicate that this can probably be correlated to the intensity of the fire during the deposition or to the reduction of fuel in its final moments.

In addition, the present work demonstrates that paleo-wildfires in the Paraná Basin were more common than previously considered, and increasing research on these and other charcoal occurrences will probably help to solve the "problem of Gondwana inertinities" (Scott 2000 p. 308).

\section{CONCLUSIONS}

From the evidence presented here, it is possible to draw the following conclusions:

(1) The charcoalified plant remains from the Faxinal Coalfield (Rio Bonito Formation) testify to the occurrence of wildfires in this area during the Early Permian (Sakmarian).
(2) It is possible to propose that the volcanic activities in nearby areas were among the sources of ignition for wildfires registered in the tonstein layer studied in this analysis.

(3) The mostly well-preserved charred plant fragments support the hypothesis of autochtonous/parautochtonous origin for the material.

(4) The wood remains are related to gymnosperms (Agathoxylon?).

(5) The dominance of Glossopteris spp. in the association could support a correlation between the wood remains and this genus.

\section{ACKNOWLEDGMENTS}

We thank Claudia Franz, Senckenberg Forschungsinstitut und Naturmuseum Frankfurt, for technical assistance with SEM facilities. A. Jasper acknowledges financial support by Fundação de Amparo à Pesquisa do Estado do Rio Grande do Sul (FAPERGS) and Conselho Nacional de Desenvolvimento Científico e Tecnológico (CNPq). M. Guerra-Sommer acknowledges financial support by CNPq. We also thank the two anonymous referees of Anais da Academia Brasileira de Ciências for the detailed revision and important suggestions to improve this paper.

\section{RESUMO}

Charcoal fóssil foi encontrado na Mina do Faxinal, Permiano Inferior, Formação Rio Bonito, na porção sul da Bacia do Paraná, Brasil. Foram descritos três tipos de lenhos gimnospérmicos picnoxílicos originários de um único nível de tonstein, o que confirma a ocorrência de paleoincêndios vegetacionais nesta área. Uma redução da concentração de charcoal da base para o topo no nível de tonstein indica que a quantidade de combustível diminuiu durante a deposição, provavelmente devido ao consumo da vegetação existente pelo fogo. A presença de inertinita na camada de carvão, em níveis sobrepostos e sotopostos ao tonstein, indica que incêndios não estavam restritos ao intervalo de deposição da cinza vulcânica. A integração dos novos dados aqui apresentados com outros publicados anteriormente acerca da Mina do Faxinal, demonstra que eventos vulcânicos ocorridos nas áreas circunvizinhas podem ser identificados como potenciais fatores de ignição para os incêndios. A presença de chacoal em sedimentos associados a níveis de carvão em diferentes localidades no 
Permiano, demonstra que incêndios vegetacionais foram relativamente comuns nos ambientes formadores dos depósitos de carvão da Bacia do Paraná.

Palavras-chave: charcoal, gimnospermas, cinzas vulcânicas, depósitos de carvão, Gondwana, Paleozóico Superior.

\section{REFERENCES}

BAMFORD MK AND PhiLIPPE M. 2001. Jurassic-Early Cretaceous Gondwanan homoxylous woods: a nomenclatural revision of the genera with taxonomic notes. Rev Palaeobot Palynol 113: 287-297.

Bowman DMJS ET AL. 2009. Fire in the Earth System. Science 324: 481-484.

Cazzulo-Klepzig M, Guerra-Sommer M And MeneGAT R. 2007. Peat forming environment of Permian coal seams from the Faxinal Coalfield (Paraná Basin) in Southern Brazil, based on Palynology and Palaeobotany. Rev Bras Paleont 10: 117-127.

DiAs MER AND GUERRA-Sommer M. 1994. Integração entre dados mega e microflorísticos da Jazica do Faxinal, Rio Grande do Sul: estudos preliminares. Acta Geol Leopold 39: 249-260.

DIESSEL CFK. 2010. The stratigraphic distribution of inertinite. Int J Coal Geol 81: 251-268.

DiMichele WA, Hook RW, Nelson WJ And Chaney DS. 2004. An unusual Middle Permian flora from the Blaine Formation (Pease River Group: Leonardian-Guadalupian Series) of King County, West Texas. Jour Paleont 78: 765-782.

FLANNIGAN MD, KRAWCHUK MA, GRoOT WJ DE, WotTON BM AND GOWMAN LM. 2009. Implications of changing climate for global wildland fire. Int J Wildland Fire 18: 483-507.

Formoso Mll, Calarge LM, Garcia AJV, Alves DB, Gomes MEB And Misuzaki AM. 1999. Permian tonsteins from the Paraná Basin, Rio Grande do Sul, Brazil. Proceedings of the XI International Clay Conference, p. 613-621.

Gastaldo RA, DiMichele WA ANd Pfefferkorn HW. 1996. Out of the Icehouse into the Greenhouse: a Late Paleozoic Analog for modern global vegetational change. GSA Today 6: 2-7.

GLASSPOOL IJ. 2000. A major fire event recorded in the mesofossils and petrology of the Late Permian, Lower Whybrow coal seam, Sydney Basin, Australia. Palaeogeogr Palaeoclim Palaeoecol 164: 373-396.

Glasspool IJ. 2003. Hypautochtonous-allochtonous coal deposition in the Permian, South African, Witbank Basin
No. 2 seam; a combined approach using sedimentology, coal petrology and palaeontology. Int J Coal Geol 53: 81-135.

Guerra-Sommer M. 1992. Padrões epidérmicos de Glossopterídales da tafoflora de Faxinal (Formação Rio Bonito, Artinskiano/Kunguriano, Bacia do Paraná, Brasil). Pesquisas 19: 26-40.

Guerra-Sommer M, CAZZulo-KLepzig M, Formoso MLL, Menegat R And Mendonça F? JG. 2008a. $\mathrm{U}-\mathrm{Pb}$ dating of tonstein layers from a coal sucession of the southern Paraná Basin (Brazil): a new geochronological approach. Gond Research 14: 474-482.

Guerra-Sommer M, CAZZulo-KLepzig M, Menegat R, Formoso MLL, BASEI MAS, BARBOZA EG AND SimAS MW. 2008b. Geochronological data from the Faxinal coal sucession, southern Paraná Basin, Brazil: a preliminary approach combining radiometric $\mathrm{U}-\mathrm{Pb}$ dating and palynostratigraphy. J South Am Earth Sc 25: 246256.

Guerra-Sommer M, CAZZUlo-Klepzig M, SANTos JOS, Hartmann LA, Ketzer JM And Formoso MLL. 2008c. Radiometric age determination of tonstein and stratigraphic constrains for the Lower Permian coal succession in southern Paraná Basin, Brazil. Int J Coal Geol 74: 13-27.

Guerra-Sommer M, Marques-Toigo M, Paim PSG, Heiz GI, Silveira VBR AND BACKhauser Y. 1984. Estudo microflorístico e petrológico dos carvões da Mina do Faxinal, Formação Rio Bonito, Permiano. Bol IG/USP 15: 73-83.

Guerra-Sommer M, Santos JOS, Cazzulo-Klepzig M, Hartmann LA, Menegat R and McNaughton NJ. 2006. The geochronological significance of tonstein in coal-bearing strata from the southern Paraná Basin. Proceedings from South American Symposium on Isotope Geology 5: 254-257.

Holz M. 1998. The Eopermian coal seams of the Paraná Basin in southernmost Brazil: an analysis of the depositional conditions using stratigraphy concepts. Int J Coal Geol 36: 141-163.

Jasper A, Guerra-Sommer M, Uhl D, SAlvi J, KaufFMANN M, OSTERKAMP IC AND GONÇALVES CV. 2007. A ocorrência de incêndios vegetacionais durante o Paleozóico Superior da Bacia do Paraná. In: CARVALHO I, CAssab RCT, Schwanke C, Carvalho MA, FERNANdes ACS, Rodrigues MAC, Carvalho MSS, Arai M ANd Oliveira MEQ (Eds), Paleontologia: Cenários de Vida, Editora Interciência 1: 14-25.

Jasper A, Menegat R, Guerra-Sommer M, CazzuloKlePZig M AND Souza PA. 2006. Depositional cyclic- 
ity and paleoecological variability in an outcrop of Rio Bonito formation, Early Permian, Paraná Basin, Rio Grande do Sul, Brazil. J South Am Earth Sc 21: 276-293.

JAsper A, Uhl D, Guerra-Sommer M And MosbrugGER V. 2008. Palaeobotanical evidence of wildfires in the Late Palaeozoic of South America - Early Permian, Rio Bonito Formation, Paraná Basin, Rio Grande do Sul, Brazil. J South Am Earth Sc 26: 435-444.

Jones TP AND Chaloner WG. 1991. Fossil charcoal, its recognition and palaeoatmospheric significance. Palaeogeogr Palaeoclim Palaeoecol 97: 39-50.

Kalkreuth W, Holz KM, Machado G, Mexias A, Silva MB, Willett J, Finkelman R and Burger H. 2006. Petrology and chemistry of Permian coals from the Paraná Basin: 1. Santa Terezinha, Leão-Butiá and Candiota Coalfields, Rio Grande do Sul, Brazil. Int J Coal Geol 68: 79-116.

Milani EJ. 2003. Estratigrafia da Bacia do Paraná-Algumas considerações metodológicas. Anais do Encontro sobre Estratigrafia do Rio Grande do Sul: Escudo e Bacias 1: $18-22$.

Noll R, Uhl D And Lausberg S. 2003. Brandstrukturen an Kieselhölzern der Donnersberg Formation (Oberes Rotliegen, Unterperm) des Saar-Nahe Beckens (SW-Deutschland). Veröffentlichungen Museum für Naturkunde Chemnitz 26: 63-72.

Philippe M. 1993. Nomenclature générique des trachéidoxyles mésozoïques a champs araucarioïdes. Taxon 42 : $74-80$.

Philippe M AND BAMFord MK. 2008. A key to morphogenera used for Mesozoic conifer-like woods. Rev Palaeobot Palynol 148: 184-207.

Prevec R, Labandeira CC, Neveling J, Gastaldo RA, Looy CV AND BAMford M. 2009. Portrait of Gondwana ecosystem: a new Late Permian locality from KwaZulu-Natal, South Africa. Rev Palaeobot Palynol 156: 454-493.

Rees PM, Gibbs MT, Ziegler AM, Kutzbach JE AND BEHLING PJ. 1999. Permian climates: evaluating model predictions using global paleobotanical data. Geology 27: 891-894.

Ribeiro NVB, Freitas JI AND CAmozatto E. 1987. Análise paleoambiental das jazidas de carvão do Estado do Rio Grande do Sul. Estudos Tecnológicos 10: 15-54.
RÖßLER R (ED). 2001. Der Versteinerte Wald von Chemnitz. Museum für Naturkunde Chemnitz, $252 \mathrm{p}$.

SCOTESE CR. 2002. Paleomap project (s.n.t.). Available at $<$ http://www.scotese.com> (accessed 09.15.2009).

SCOTT AC. 1989. Observations on the nature and origin of fusain. Int J Coal Geol 12: 443-475.

SCOTT AC. 2000. The pre-quaternary history of fire. Palaeogeogr Palaeoclim Palaeoecol 164: 281-329.

ScotT AC. 2010. Charcoal recognition, taphonomy and uses in palaeoenvironmental analysis. Palaeogeogr Palaeoclim Palaeoecol 291: 11-39.

SCOTT AC AND GLAsspool I. 2007. Observations and experiments on the origin and formation of inertinite group macerals. Int J Coal Geol 70: 53-66.

ŠIMÙNEK Z AND MARTíneK K. 2009. A study of Late Carboniferous and Early Permian plant assemblages from the Boskovice Basin, Czech Republic. Rev Palaeobot Palynol 155: 275-307.

Uhl D, Abu Hamad AMB, Kerp H and Bandel K. 2007. Evidence for palaeo-wildfire in the Late Permian palaeotropics - charcoalified wood from the Um Irna Formation of Jordan. Rev Palaeobot Palynol 144: 221-230.

Uhl D, Jasper A, Abu Hamad AMB and Montenari M. 2008. Permian and Triassic wildfires and atmospheric oxygen levels. Proceedings from the WSEAS International Conference on Environmental and Geological Science and Engineering - Special Issues 1: 179-188.

UHL D AND KerP H. 2003. Wildfires in the Late Palaeozoic of Central Europe - The Zechstein (Upper Permian) of NW Hesse (Germany).Palaeogeogr Palaeoclim Palaeoecol 199: $1-15$.

Uhl D, Lausberg S, Noll R and Stapf KRG. 2004. Wildfires in the Late Palaeozoic of Central Europe an overview of the Rotliegend (Upper CarboniferousLower Permian) of the Saar-Nahe Basin (SW-Germany). Palaeogeogr Palaeoclim Palaeoecol 207: 23-35.

Vogellehner D. 1964. Zur Nomenklatur der fossilien Holzgattung Dadoxylon Endlicher 1847. Taxon 13: 233237.

WANG Z AND CHEN A. 2001. Traces of arborescent lycopsids and dieback of the forest vegetation in relation to terminal Permian mass extinction in North China. Rev Palaeobot Palynol 117: 217-243. 